\title{
ALTERNATIF PEMAKAIAN AGREGAT LEMPUNG BAKAR PADA BETON RINGAN NON PASIR
}

\author{
Alternative Fuel Use of Aggregate Clay Lightweight Concrete in Non Sand
}

\author{
${\text { Fahrudin Safi }{ }^{1} \& \text { Rofikatul Kharimah }}^{2}$
}

\author{
1,2Jurusan Sipil Fakultas Teknik Universitas Muhammadiyah Malang \\ Alamat korespondensi : Jl. Raya Tlogomas No.246, Malang (0341) 464318 \\ Email : ${ }^{1)}$ fahrudinsafi@yahoo.com
}

\begin{abstract}
Abstrack
The aggregate light is a component in the form of light concrete. With engineering technology, making up an aggregate attempted light artificial (Artifical Lightweight Agregates) that are still meet the standards the aggregate concrete. One of engineering would check is artificial making up an aggregate of loam that is burned $800^{\circ} \mathrm{C}$ with the temperature, $900^{\circ} \mathrm{C}, 1000^{\circ} \mathrm{C}, 1100^{\circ} \mathrm{C}$, and $1200^{\circ} \mathrm{C}$, due the loam across Indonesia is evenly in almost all the area.Test objects made in this research as many as 36 objects the size of the cylindrical $150 \times 300 \mathrm{~mm}$ and 18 objects the cube size $50 \times 50 \times 50 \mathrm{~mm}$. Research based on the results obtained a compressive force concrete maximum non the sand by the aggregate loam fuel at the age of 28 days of $14.10 \mathrm{MPa} 12000^{\circ} \mathrm{C}$ in temperature, tensile strength maximum countries concrete at a temperature of $12000^{\circ} \mathrm{C} 0.66$ of MPa, the porosity of concrete maximum of $17.10 \% 8000^{\circ} \mathrm{C}$ at a temperature of, and concrete modulo elasticity of 20540.167 minimum $\mathrm{KN} / \mathrm{cm}^{2}$.
\end{abstract}

Keywords : Aggregate, clay fuel, lightweight concrete non sand

\begin{abstract}
Abstrak
Agregat adalah komponen berupa beton ringan .Dengan teknologi rekayasa, membuat agregat berusaha buatan cahaya ( Buatan Ringan agregat ) yang masih memenuhi standar beton agregat . Salah satu teknik yang akan memeriksa adalah buatan membuat sebuah agregat lempung yang dibakar 8000C dengan suhu , 9000C, 10000C , 11000C , dan 12000C , karena pada lempung di Indonesia adalah merata di hampir semua daerah .test benda yang terbuat dalam penelitian ini sebagai sebanyak 36 benda ukuran silinder 150 x $300 \mathrm{~mm}$ dan 18 objek ukuran kubus 50 × 50 x $50 \mathrm{~mm}$. Penelitian berdasarkan hasil yang diperoleh kekuatan tekan beton maksimum non pasir dengan bahan bakar lempung agregat pada usia 28 hari dari $14.10 \mathrm{MPa} 120000 \mathrm{C}$ suhu, kekuatan tarik negara maksimum beton pada suhu 120000C 0.66 dari MPa, porositas beton maksimum 17.10\% 80000C pada suhu, dan elastisitas modulo beton 20.540,167 minimal KN/ cm2 .
\end{abstract}

Kata Kunci: Agregat, lempung bakar, beton ringan non pasir

\section{PENDAHULUAN}

Pada dasarnya ada tiga komponen dasar bahan yang dapat digunakan untuk struktur, yaitu kayu, baja dan beton. Diantara ketiga jenis bahan tersebut yang sering dijumpai untuk konstruksi di Indonesia adalah beton. Beton adalah batu tiruan yang banyak dipakai secara luas sebagai bahan bangunan, didapatkan dari pencampuran bahan-bahan agregat halus dan kasar yaitu pasir dan kerikil dengan menambahkan bahan perekat semen dan air sebagai pembantu guna keperluan reaksi kimia selama proses dan pengawasan beton berlangsung. Beton merupakan salah satu komponen dasar yang mempunyai prioritas penggunaan dalam konstruksi yang perlu penanganan dan pengawasan secara teliti, dimana bahan-bahan penyusun beton sangat menentukan mutu beton yang baik. Sifat yang dimiliki beton tersebut menjadikan beton sebagai bahan alternatif untuk dikembangkan baik bentuk fisik maupun metode pelaksanaan dan pembuatannya.

Adapun permasalahan dalam penelitian ini adalah bagaimana karakteristik dan suhu ideal agregat buatan lempung bakar dengan variasi suhu $800^{\circ} \mathrm{C}-1200^{\circ} \mathrm{C}$, serta berapa besar nilai kuat tekan, kuat tarik belah, porositas, dan modulus elastisitas 
beton ringan non pasir dengan agregat buatan lempung bakar.

Tujuan dari penelitian ini adalah mengetahui suhu ideal, berat jenis, penyerapan air (absorbsi), tingkat keausan agregat buatan lempung bakar dengan variasi suhu $800^{\circ} \mathrm{C}-1200^{\circ} \mathrm{C}$ dan untuk mengetahui berapa besar nilai kuat tekan, kuat tarik belah, porositas, dan modulus elastisitas beton ringan non pasir dengan agregat buatan lempung bakar sehingga nantinya dapat menghasilkan sebuah output beton ringan non-pasir yang bisa dimanfaatkan untuk struktur ringan pada dinding rumah tinggal sederhana.

Manfaat dilakukannya penelitian ini adalah memberikan sebuah wawasan dan informasi yang baru kepada peneliti sendiri dalam pemanfaatan sumber alam alternatif (tanah lempung) sebagai agregat ringan buatan untuk beton non-pasir serta memberikan nilai ekonomis tersendiri bagi masyarakat untuk membuka sebuah lapangan usaha yang baru.

\section{METODE PENELITIAN}

\section{Rancangan Penelitian}

Hal pertama yang dilakukan sebelum benda uji dibuat yakni dilakukan pemeriksaan bahan-bahan yang diperlukan pada saat penelitian. Proses pembuatan agregat kasar (lempung bakar dengan proporsi air tertentu) dilakukan di pabrik keramik di Malang. Proses pemeriksaan bahan, perawatan dan pengujian dilakukan di laboratorium Teknologi Beton Universitas Muhammadiyah Malang.

Berikut ini adalah cara pembuatan agregat lempung bakar.

- Lempung dicampur dengan air secukupnya, dan diaduk hingga tercampur secara merata.

- Campuran tersebut digiling menggunakan gilingan genteng sampai keadaan plastis (seperti bahan baku pembuatan genteng).

- $\quad$ Sebelum dibakar, lempung yang sudah dalam keadaan plastis tadi dibentuk (kotak, segitiga, bulat) dengan gradasi yang bervariasi antara 5 $\mathrm{mm}-20 \mathrm{~mm}$ dan dikeringkan hingga mencapai kering permukaan.

- Agregat yang sudah kering dibakar dengan suhu $800^{\circ} \mathrm{C}-1200^{\circ} \mathrm{C}$.
- Gunakan termo koppel untuk mengukur perubahan suhu yang terjadi selama pembakaran berlangsung.

Setelah selesai persiapan dan pemeriksaan alat dan bahan, maka dibuatlah benda uji sebanyak 36 benda uji silinder ukuran 150 x 300 mm untuk pengujian kuat tekan, kuat tarik belah, dan modulus elastisitas beton non pasir, sementara untuk pengujian porositas beton non pasir dibuat 18 benda uji kubus dengan ukuran 50 x 50 x 50 mm.

Cara pembuatan dan perawatan benda uji adalah sebagai berikut:

- Hitung keperluan bahan susun beton yang meliputi semen, agregat lempung bakar, dan air.

- Agregat dalam keadaan SSD.

- Untuk pengadukan beton tersebut, agregat lempung bakar dimasukan terlebih dahulu kemudian semen, setelah semen tercampur merata dengan agregatnya baru dimasukkan air. Selanjutnya pengadukan ditunggu selama \pm 4 menit agar tercampur merata.

- $\quad$ Adukan dimasukkan kedalam silinder baja yang telah dilumuri oli, dimana setiap sepertiga isi silinder ditusuk merata sebanyak 25 kali dengan batang baja atau dilakukan pemadatan dengan mesin pemadat. Setelah 24 jam benda uji dilepas dari cetakan, diberi kode, kemudian direndam untuk perawatan dalam air selama 28 hari.

- $\quad$ Setelah 28 hari, benda uji dikeluarkan, diukur diameter, tinggi dan beratnya, kemudian dilakukan pengujian kuat tekan, kuat tarik belah, porositas, dan modulus elastisitasnya.

Untuk lebih jelasnya dapat dilihat pada tabel properti benda uji berikut ini. 
Tabel 1. Properti Benda Uji Lempung Bakar

\begin{tabular}{ccccccccc}
\hline $\begin{array}{c}\text { Jenis } \\
\text { Pengujian }\end{array}$ & $\begin{array}{c}\text { Ukuran Benda } \\
\text { Uji (mm) }\end{array}$ & $\begin{array}{c}800 \\
{ }^{0} \mathrm{C}\end{array}$ & $\begin{array}{c}900 \\
{ }^{0} \mathrm{C}\end{array}$ & $\begin{array}{c}1000 \\
{ }^{0} \mathrm{C}\end{array}$ & $\begin{array}{c}1100 \\
{ }^{0} \mathrm{C}\end{array}$ & $\begin{array}{c}1200 \\
{ }^{0} \mathrm{C}\end{array}$ & $\begin{array}{c}\text { Jumlah } \\
\text { Benda Uji }\end{array}$ & $\begin{array}{c}\text { Total } \\
\text { Benda } \\
\text { Uji }\end{array}$ \\
\hline $\begin{array}{c}\text { Kuat Tekan } \\
\text { \& Modulus } \\
\text { Elastisitas }\end{array}$ & $150 \times 300$ & 3 & 3 & 3 & 3 & 3 & 15 & \\
$\begin{array}{c}\text { Kuat Tarik } \\
\quad \text { Belah }\end{array}$ & $150 \times 300$ & 3 & 3 & 3 & 3 & 3 & 15 & \\
Porositas & $50 \times 50 \times 50$ & 3 & 3 & 3 & 3 & 3 & 15 & 15 \\
\hline
\end{tabular}

Tabel 2. Properti Benda Uji Pengontrol

\begin{tabular}{cccc}
\hline Jenis Pengujian & $\begin{array}{c}\text { Ukuran Benda Uji } \\
(\mathrm{mm})\end{array}$ & Jumlah Benda Uji & Total Benda Uji \\
\hline Kuat Tekan \& Modulus & $150 \times 300$ & 3 & 6 \\
Elastisitas & $150 \times 300$ & 3 & 3 \\
Kuat Tarik Belah & $50 \times 50 \times 50$ & 3 & \\
Porositas & &
\end{tabular}

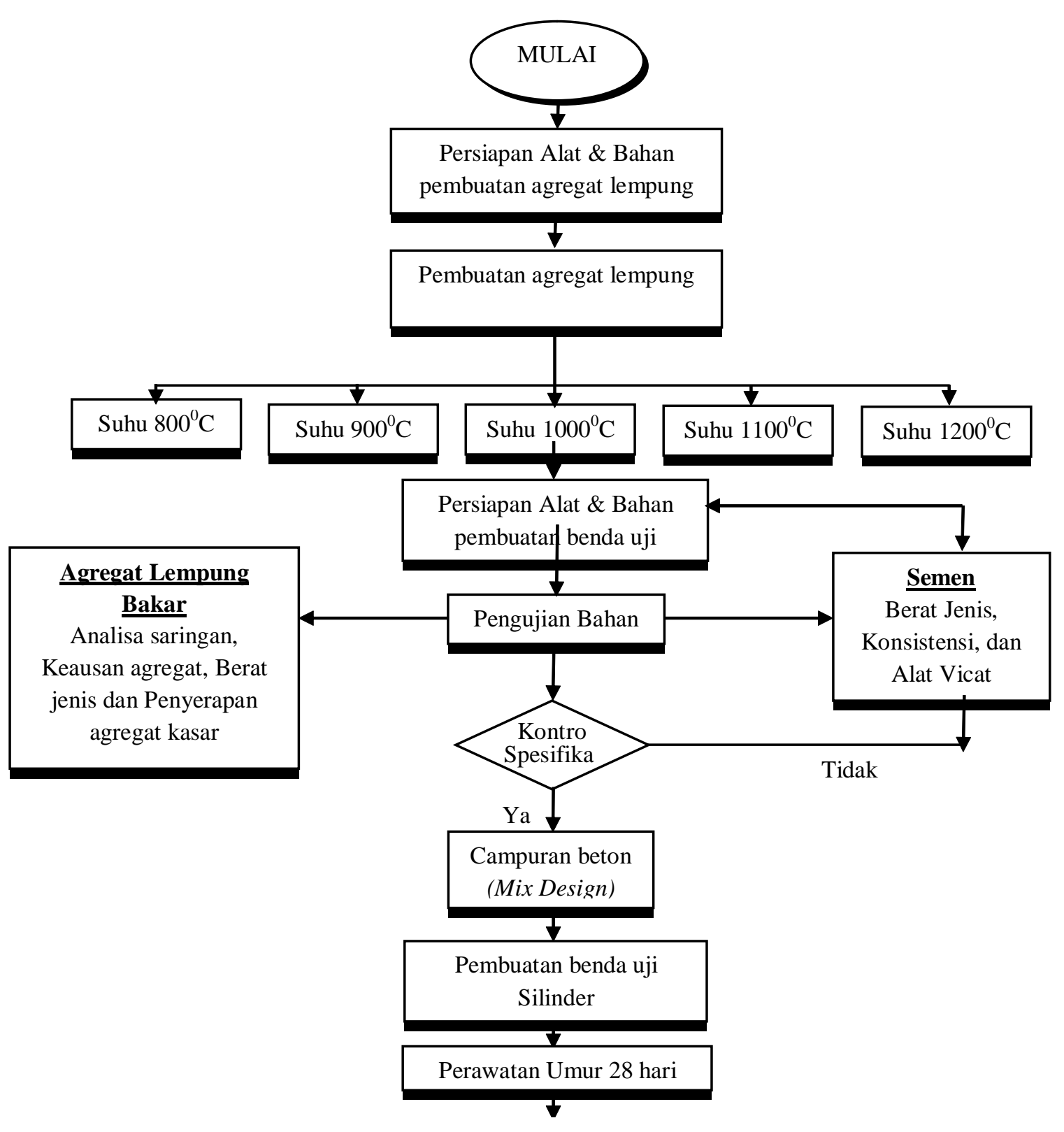




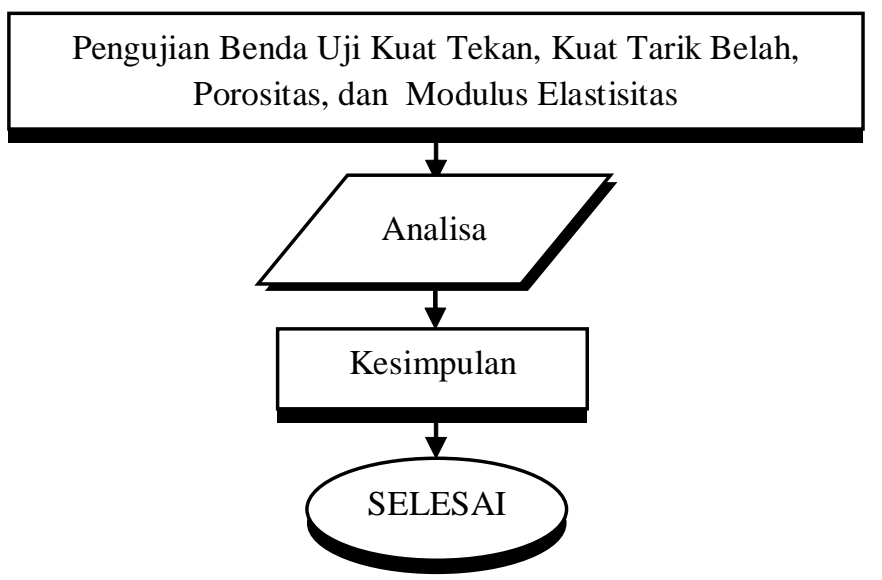

Gambar 1. Diagram Alur Penelitian

HASIL DAN PEMBAHASAN

Analisa Hasil Pengujian Semen

Tabel 3. Hasil Pemeriksaan Semen

\begin{tabular}{cccc}
\hline Jenis Pemeriksaan & Standar & Hasil Pengujian & Syarat \\
\hline Berat Jenis & SNI 15-2531-1991 & $3.160 \mathrm{gr} / \mathrm{cm}^{3}$ & $3.15-3.17 \mathrm{gr} / \mathrm{cm}^{3}$ \\
Konsistensi & SNI 03-6826-2002 & $26.2 \%$ & - \\
Waktu ikat awal & SNI 03-6827-2002 & 195 menit & Lebih dari 60 menit \\
Waktu ikat akhir & SNI 03-6827-2002 & 240 menit & Kurang dari 8 jam \\
\hline
\end{tabular}

Sumber : Hasil Penelitian

Hasil pemeriksaan berat jenis semen $\pm 10 \mathrm{~mm}$ pada alat vicat yaitu pada kadar air $26.2 \%$. didapatkan berat jenis semen rata-rata sebesar 3.160 gram $/ \mathrm{cm}^{3}$ yang artinya bahwa semen tersebut memenuhi syarat berat jenis yaitu sekitar $3.15-3.17$ gram $/ \mathrm{cm}^{3}$, sehingga layak digunakan sebagai campuran beton.

Sementara pada pengujian karakteristik semen, didapatkan nilai konsistensi normal dari penurunan

Untuk pemeriksaan waktu ikat semen diperoleh waktu ikat awal sebesar 195 menit dan waktu ikat akhir ( yaitu saat jarum vikat tidak bisa masuk lagi atau skala menunjukkan 0 ) sebesar 240 menit.

\section{Analisa Hasil Pengujian Agregat Kasar}

Tabel 4. Hasil Pemeriksaan Agregat Kasar

\begin{tabular}{|c|c|c|c|}
\hline Jenis Pemeriksaan & Standar & Hasil Pengujian & Syarat \\
\hline \multicolumn{4}{|c|}{ Agregat Lempung Bakar } \\
\hline Analisa Saringan & SNI 03-1968-1990 & $\mathrm{FM}=5.019$ & $5-8$ \\
\hline Berat Jenis & SNI 1969-2008 & $1.97 \mathrm{gr} / \mathrm{cm}^{3}$ & Kurang dari 2.0 \\
\hline Absorbsi & SNI 1969-2008 & $24.5 \%$ & - \\
\hline Abrasi & SNI 2417-2008 & $30.78 \%$ & Maksimal $40 \%$ \\
\hline \multicolumn{4}{|c|}{ Agregat Normal ( Batu Pecah ) } \\
\hline Analisa Saringan & SNI 03-1968-1990 & $\mathrm{FM}=5.047$ & $5-8$ \\
\hline Berat Jenis & SNI 1969-2008 & $2.65 \mathrm{gr} / \mathrm{cm}^{3}$ & $2.50-2.70 \mathrm{gr} / \mathrm{cm}^{3}$ \\
\hline Absorbsi & SNI 1969-2008 & $2.456 \%$ & Kurang dari $3 \%$ \\
\hline Abrasi & SNI 2417-2008 & $28.8 \%$ & Maksimal $40 \%$ \\
\hline
\end{tabular}

Sumber :Hasil Penelitian

\section{Pengujian Kuat Tekan Beton Non Pasir}

Pengujian kuat tekan beton non pasir dapat dilihat pada tabel 5 berikut ini. 
Tabel 5. Hasil Pengujian Kuat Tekan Beton Non Pasir

\begin{tabular}{|c|c|c|c|c|c|c|c|c|}
\hline $\begin{array}{c}\text { Variasi } \\
\text { Suhu } \\
\left({ }^{0} \mathrm{C}\right)\end{array}$ & $\begin{array}{l}\text { Kode } \\
\text { Bend } \\
\text { a Uji }\end{array}$ & $\begin{array}{c}\text { Umur } \\
\text { perawat } \\
\text { an (hari) }\end{array}$ & $\begin{array}{c}\text { Dial } \\
\text { beban } \\
(\mathrm{KN})\end{array}$ & $\begin{array}{c}\text { Beban } \\
\max (\mathbf{N})\end{array}$ & $\begin{array}{c}\text { Kuat } \\
\text { tekan, } \\
\text { umur } \\
28 \text { hari } \\
\text { (MPa) }\end{array}$ & $\begin{array}{c}\text { Kuat } \\
\text { tekan } \\
\text { rata- } \\
\text { rata, } \\
\text { umur 28 } \\
\text { hari } \\
(\mathrm{MPa}) \\
\end{array}$ & $\begin{array}{c}\text { Penurun } \\
\text { an Kuat } \\
\text { tekan } \\
\text { (MPa) }\end{array}$ & $\begin{array}{c}\text { Persenta } \\
\text { se } \\
\text { Penurun } \\
\text { an Kuat } \\
\text { tekan } \\
(\%)\end{array}$ \\
\hline \multirow{3}{*}{800} & S-1 & 28 & 145 & 145000 & 8.21 & \multirow{3}{*}{7.93} & \multirow{3}{*}{12.23} & \multirow{3}{*}{60.67} \\
\hline & S-2 & 28 & 120 & 120000 & 6.79 & & & \\
\hline & S-3 & 28 & 155 & 155000 & 8.78 & & & \\
\hline \multirow{3}{*}{900} & S-1-1 & 28 & 130 & 130000 & 7.36 & \multirow{3}{*}{7.45} & \multirow{3}{*}{12.70} & \multirow{3}{*}{63.01} \\
\hline & S-1-2 & 28 & 125 & 125000 & 7.08 & & & \\
\hline & $S-1-3$ & 28 & 140 & 140000 & 7.93 & & & \\
\hline \multirow{3}{*}{1000} & S-2-1 & 28 & 205 & 205000 & 11.61 & \multirow{3}{*}{11.83} & \multirow{3}{*}{8.32} & \multirow{3}{*}{41.29} \\
\hline & S-2-2 & 28 & 207 & 207000 & 11.72 & & & \\
\hline & S-2-3 & 28 & 215 & 215000 & 12.17 & & & \\
\hline \multirow{3}{*}{1100} & S-3-1 & 28 & 200 & 200000 & 11.32 & \multirow{3}{*}{12.32} & \multirow{3}{*}{7.83} & \multirow{3}{*}{38.86} \\
\hline & S-3-2 & 28 & 238 & 238000 & 13.47 & & & \\
\hline & S-3-3 & 28 & 215 & 215000 & 12.17 & & & \\
\hline \multirow{3}{*}{1200} & S-4-1 & 28 & 245 & 245000 & 13.87 & \multirow{3}{*}{14.10} & \multirow{3}{*}{6.06} & \multirow{3}{*}{30.06} \\
\hline & S-4-2 & 28 & 247 & 247000 & 13.98 & & & \\
\hline & S-4-3 & 28 & 255 & 255000 & 14.44 & & & \\
\hline
\end{tabular}

Sumber : Hasil Penelitian

Untuk perbedaan pengaruh variasi suhu dapat dilihat pada gambar 4.1 berikut ini : bakar agregat lempung terhadap kuat tekan beton

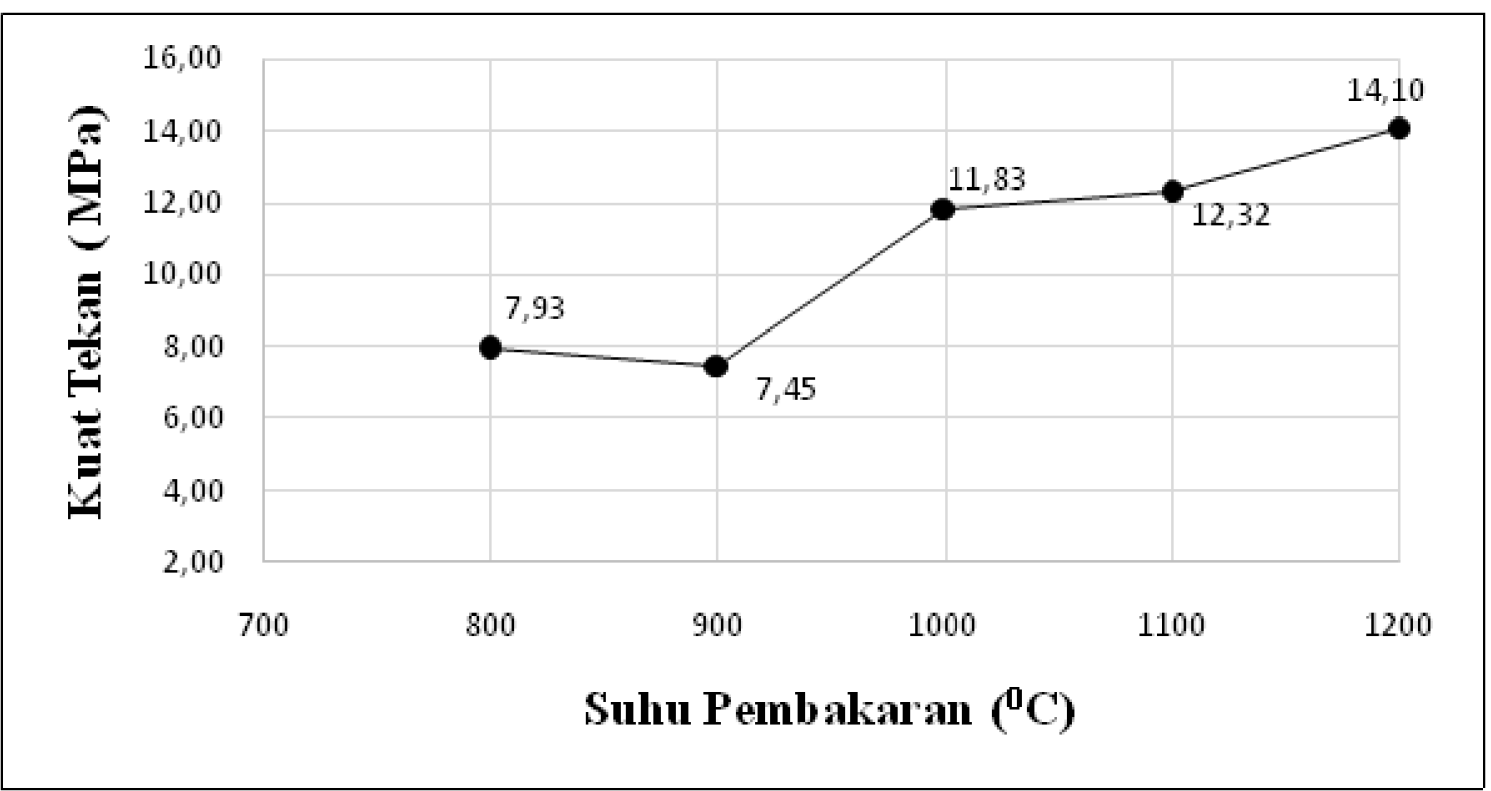

Gambar 1. Grafik Hubungan Antara Suhu Bakar Agregat lempung dengan Kuat Tekan Beton Non Pasir

\section{Pengujian Kuat Tarik Belah Beton Non Pasir}


Tabel 6. Hasil Pengujian Kuat Tarik Belah Beton Non Pasir

\begin{tabular}{|c|c|c|c|c|c|c|c|c|}
\hline $\begin{array}{c}\text { Varia } \\
\text { si } \\
\text { Suhu } \\
\left({ }^{0} C_{)}\right.\end{array}$ & $\begin{array}{c}\text { Kode } \\
\text { Benda } \\
\text { Uji }\end{array}$ & $\begin{array}{c}\text { Umur } \\
\text { perawatan } \\
\text { (hari) }\end{array}$ & $\begin{array}{c}\text { Dial } \\
\text { beban } \\
(\mathrm{KN})\end{array}$ & $\begin{array}{c}\text { Beba } \\
\mathbf{n} \\
\max \\
(\mathrm{N})\end{array}$ & $\begin{array}{l}\text { Kuat tarik } \\
\text { belah, } \\
\text { umur } 28 \\
\text { hari (MPa) }\end{array}$ & $\begin{array}{c}\text { Kuat tarik } \\
\text { belah rata- } \\
\text { rata, umur } \\
28 \text { hari } \\
\text { (MPa) }\end{array}$ & $\begin{array}{c}\text { Penurunan } \\
\text { Kuat tarik } \\
\text { belah (MPa) }\end{array}$ & $\begin{array}{l}\text { Persentase } \\
\text { Penurunan } \\
\text { Kuat tarik } \\
\text { belah }(\%)\end{array}$ \\
\hline \multirow{3}{*}{800} & S-4 & 28 & 15 & $\begin{array}{c}1500 \\
0\end{array}$ & 0.21 & \multirow{3}{*}{0.34} & \multirow{3}{*}{0.67} & \multirow{3}{*}{66.51} \\
\hline & S-5 & 28 & 24 & $\begin{array}{c}2400 \\
0\end{array}$ & 0.34 & & & \\
\hline & S-6 & 28 & 33 & $\begin{array}{c}3300 \\
0\end{array}$ & 0.47 & & & \\
\hline \multirow{3}{*}{900} & S-1-4 & 28 & 15 & $\begin{array}{c}1500 \\
0\end{array}$ & 0.21 & \multirow{3}{*}{0.22} & \multirow{3}{*}{0.79} & \multirow{3}{*}{78.14} \\
\hline & S-1-5 & 28 & 10 & $\begin{array}{c}1000 \\
0\end{array}$ & 0.14 & & & \\
\hline & S-1-6 & 28 & 22 & $\begin{array}{c}2200 \\
0\end{array}$ & 0.31 & & & \\
\hline \multirow{3}{*}{1000} & S-2-4 & 28 & 43 & $\begin{array}{c}4300 \\
0\end{array}$ & 0.61 & \multirow{3}{*}{0.52} & \multirow{3}{*}{0.50} & \multirow{3}{*}{48.84} \\
\hline & S-2-5 & 28 & 29 & $\begin{array}{c}2900 \\
0\end{array}$ & 0.41 & & & \\
\hline & S-2-6 & 28 & 38 & $\begin{array}{c}3800 \\
0\end{array}$ & 0.54 & & & \\
\hline \multirow{3}{*}{1100} & S-3-4 & 28 & 40 & $\begin{array}{c}4000 \\
0\end{array}$ & 0.57 & \multirow{3}{*}{0.58} & \multirow{3}{*}{0.43} & \multirow{3}{*}{42.79} \\
\hline & S-3-5 & 28 & 43 & $\begin{array}{c}4300 \\
0\end{array}$ & 0.61 & & & \\
\hline & S-3-6 & 28 & 40 & $\begin{array}{c}4000 \\
0\end{array}$ & 0.57 & & & \\
\hline \multirow{3}{*}{1200} & S-4-4 & 28 & 46 & $\begin{array}{c}4600 \\
0\end{array}$ & 0.65 & \multirow{3}{*}{0.66} & \multirow{3}{*}{0.36} & \multirow{3}{*}{35.35} \\
\hline & S-4-5 & 28 & 44 & $\begin{array}{c}4400 \\
0\end{array}$ & 0.62 & & & \\
\hline & S-4-6 & 28 & 49 & $\begin{array}{c}4900 \\
0\end{array}$ & 0.69 & & & \\
\hline
\end{tabular}

Sumber : Hasil Penelitian

Untuk perbedaan pengaruh variasi suhu bakar pasir dapat dilihat pada gambar 2 berikut ini : agregat lempung terhadap kuat tarik belah beton non

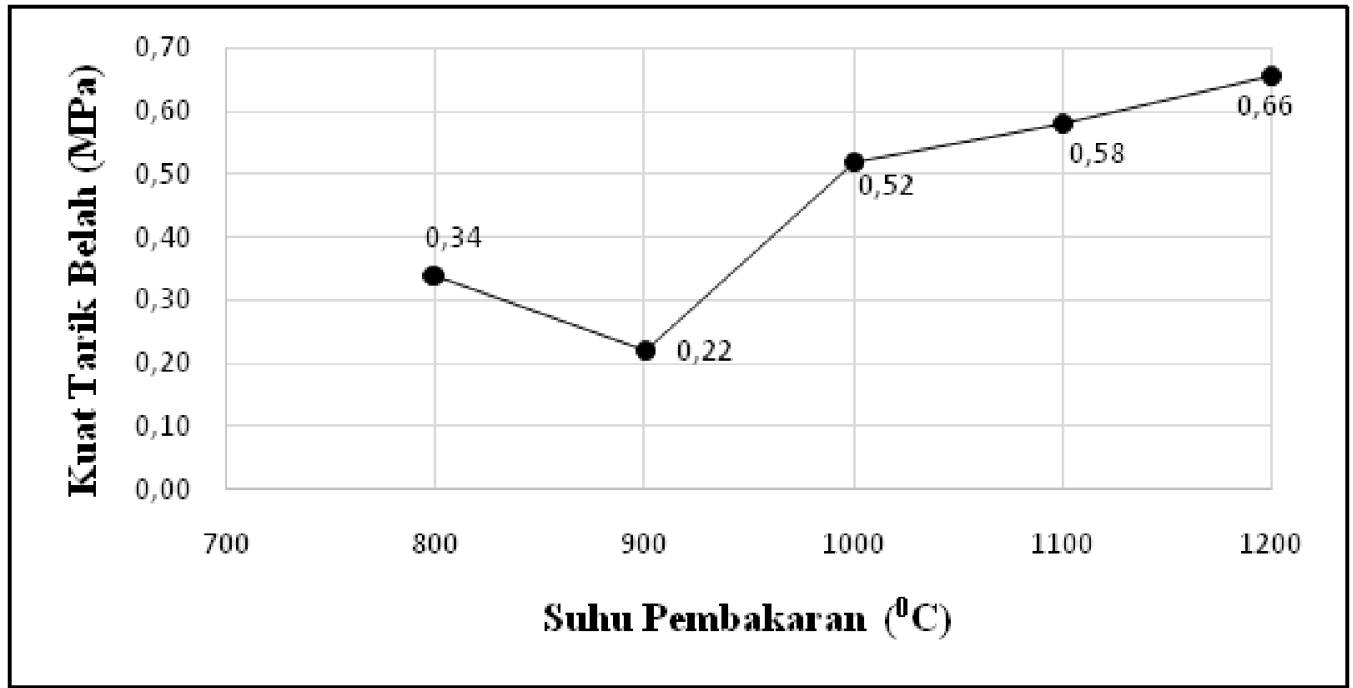

Gambar 2. Grafik Hubungan Antara Suhu Bakar Agregat lempung dengan Kuat Tarik Belah Beton Non Pasir 
Tabel 7. Hasil Pengujian Porositas Beton Non Pasir

\begin{tabular}{ccccccc}
\hline $\begin{array}{c}\text { Kode } \\
\text { Benda } \\
\text { Uji }\end{array}$ & $\begin{array}{c}\text { Suhu } \\
\left({ }^{\mathbf{C}} \mathbf{C}\right)\end{array}$ & $\begin{array}{c}\text { Berat } \\
\text { SSD } \\
\text { (gram) }\end{array}$ & $\begin{array}{c}\text { Berat } \\
\text { dalam } \\
\text { Air } \\
\text { (gram) }\end{array}$ & $\begin{array}{c}\text { Kondisi } \\
\text { Kering Oven } \\
\text { (gram) }\end{array}$ & $\begin{array}{c}\text { Porositas } \\
(\%)\end{array}$ & $\begin{array}{c}\text { Porositas } \\
\text { rata-rata } \\
\text { (\%) }\end{array}$ \\
\hline K-1 & & 256 & 125 & 230 & 19.847 & \\
K-2 & \multirow{2}{*}{800} & 268 & 127.5 & 246 & 15.658 & 17.10 \\
K-3 & & 259 & 126 & 238 & 15.789 & \\
\hline K-1-1 & & 258.5 & 130 & 239 & 15.175 & \\
K-1-2 & 900 & 259 & 127 & 238 & 15.909 & 14.50 \\
K-1-3 & & 257.5 & 128.5 & 241.5 & 12.403 & \\
\hline K-2-1 & & 255 & 122 & 231 & 18.045 & \\
K-2-2 & 1000 & 259 & 130 & 246 & 10.078 & 14.25 \\
K-2-3 & & 257 & 127 & 238 & 14.615 & \\
\hline K-3-1 & & 256.5 & 126 & 243 & 10.345 & \\
K-3-2 & 1100 & 264 & 125 & 257 & 5.036 & 13.06 \\
K-3-3 & & 259.5 & 123 & 227 & 23.810 & \\
\hline K-4-1 & & 254.5 & 129 & 235 & 15.538 & \\
K-4-2 & 1200 & 260 & 130 & 241 & 14.615 & 15.20 \\
K-4-3 & & 255 & 125.5 & 235 & 15.444 & \\
\hline & & & & & & \\
\hline
\end{tabular}

Sumber : Hasil Penelitian

Untuk lebih jelasnya dapat dilihat pada grafik dengan porositas beton non pasir berikut ini. hubungan antara suhu bakar agregat lempung

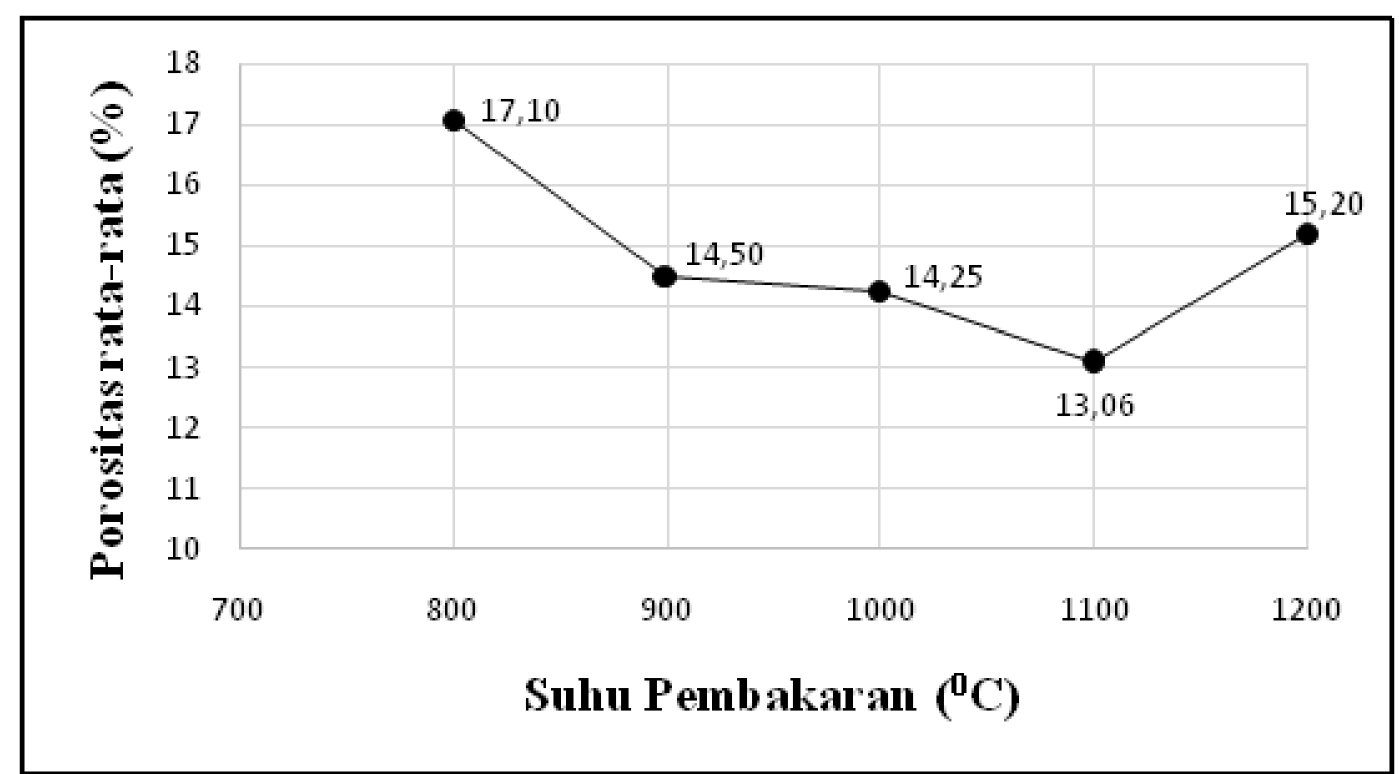

Gambar 3. Grafik Hubungan Antara Suhu Bakar Agregat 


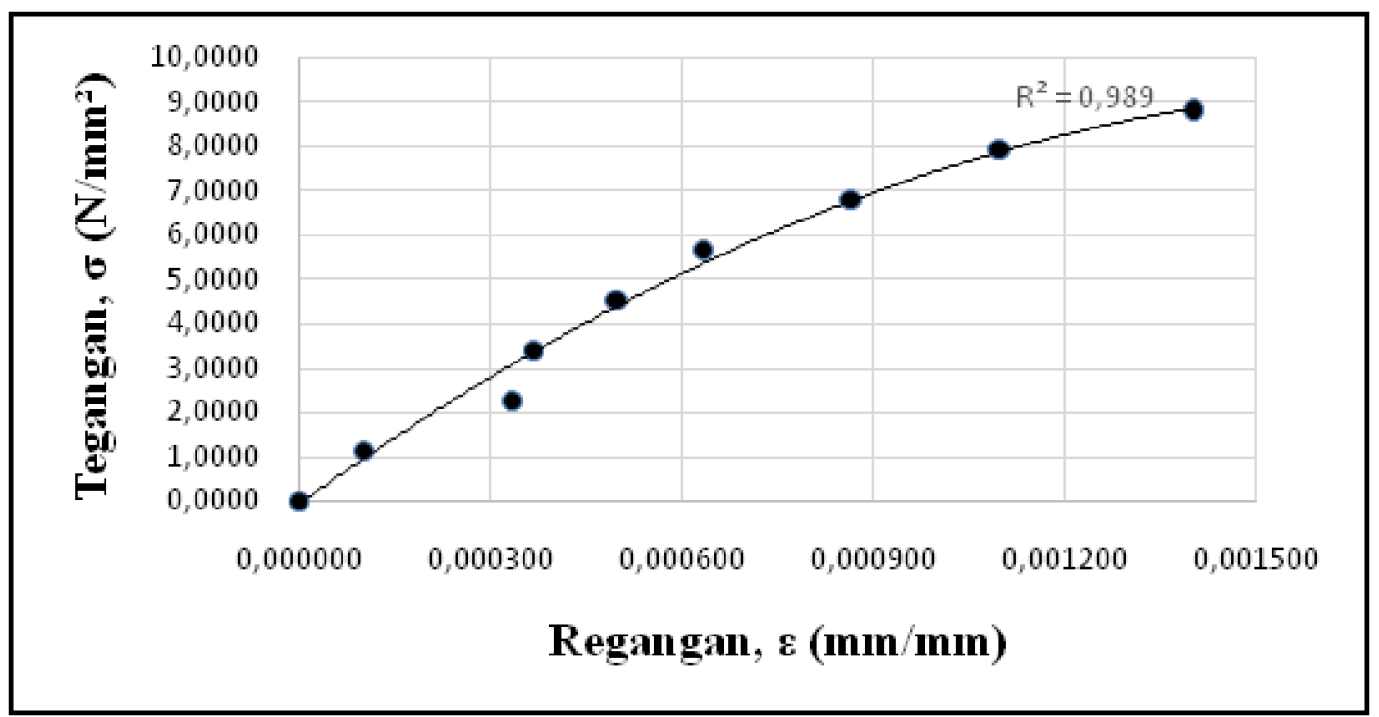

Gambar 4. Grafik Hubungan Antara Tegangan dengan Regangan Beton Non Pasir pada Suhu Bakar Agregat Lempung $800^{\circ} \mathrm{C}$

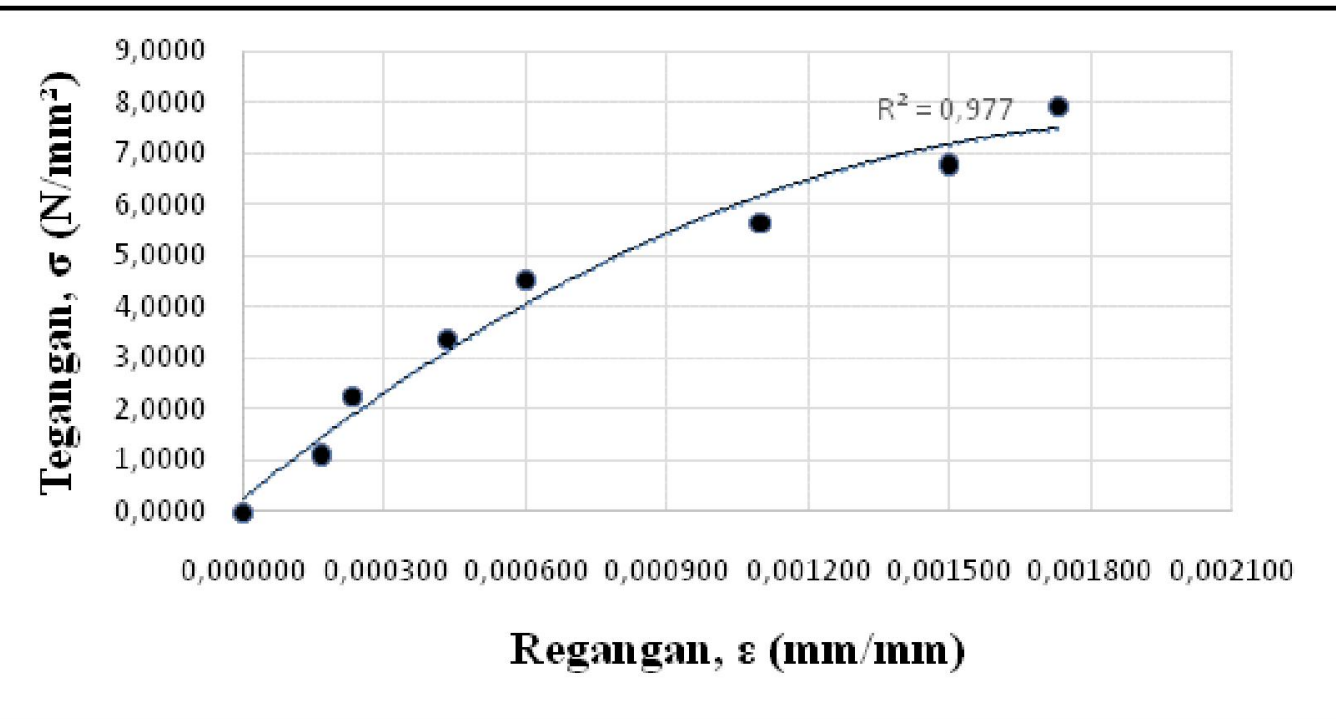

Gambar 5. Grafik Hubungan Antara Tegangan dengan Regangan Beton Non Pasir pada Suhu Bakar Agregat Lempung $900^{\circ} \mathrm{C}$

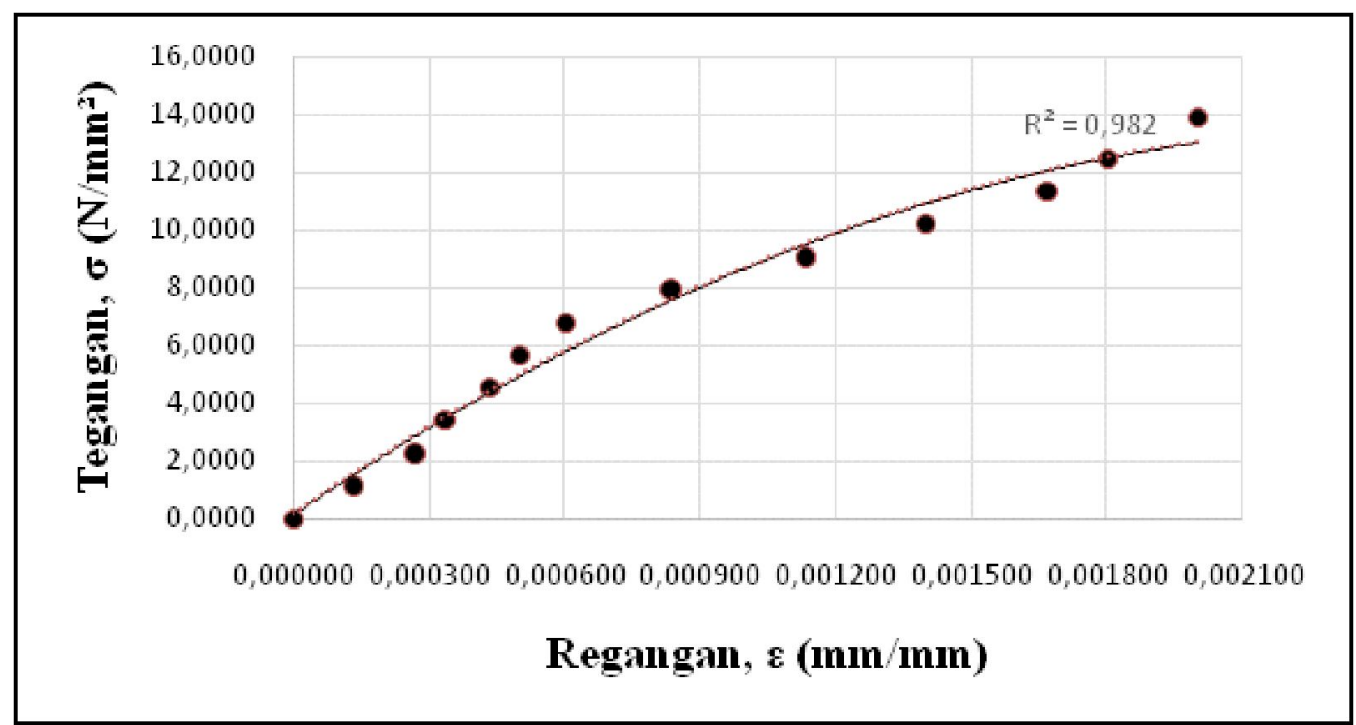

Gambar 6. Grafik Hubungan Antara Tegangan dengan Regangan Beton Non Pasir pada Suhu Bakar Agregat Lempung $1000^{\circ} \mathrm{C}$ 


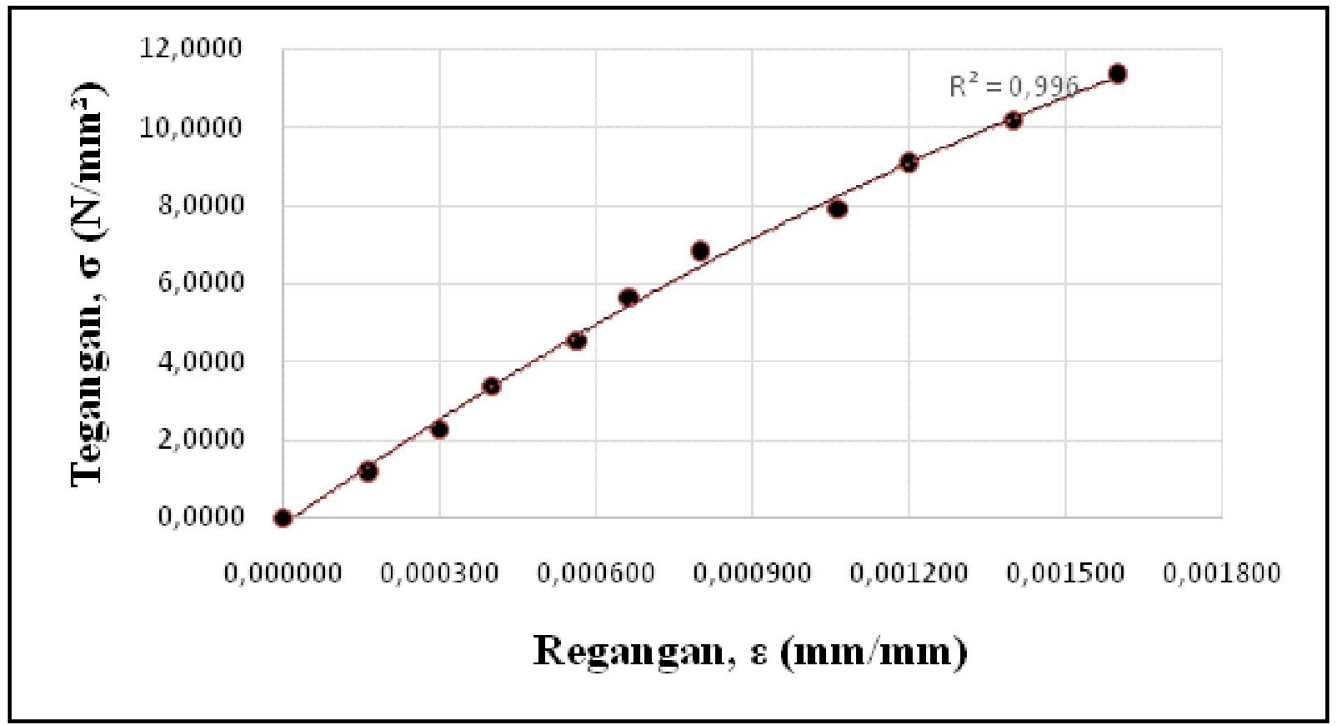

Gambar 7. Grafik Hubungan Antara Tegangan dengan Regangan Beton Non Pasir pada Suhu Bakar Agregat Lempung $1100^{\circ} \mathrm{C}$

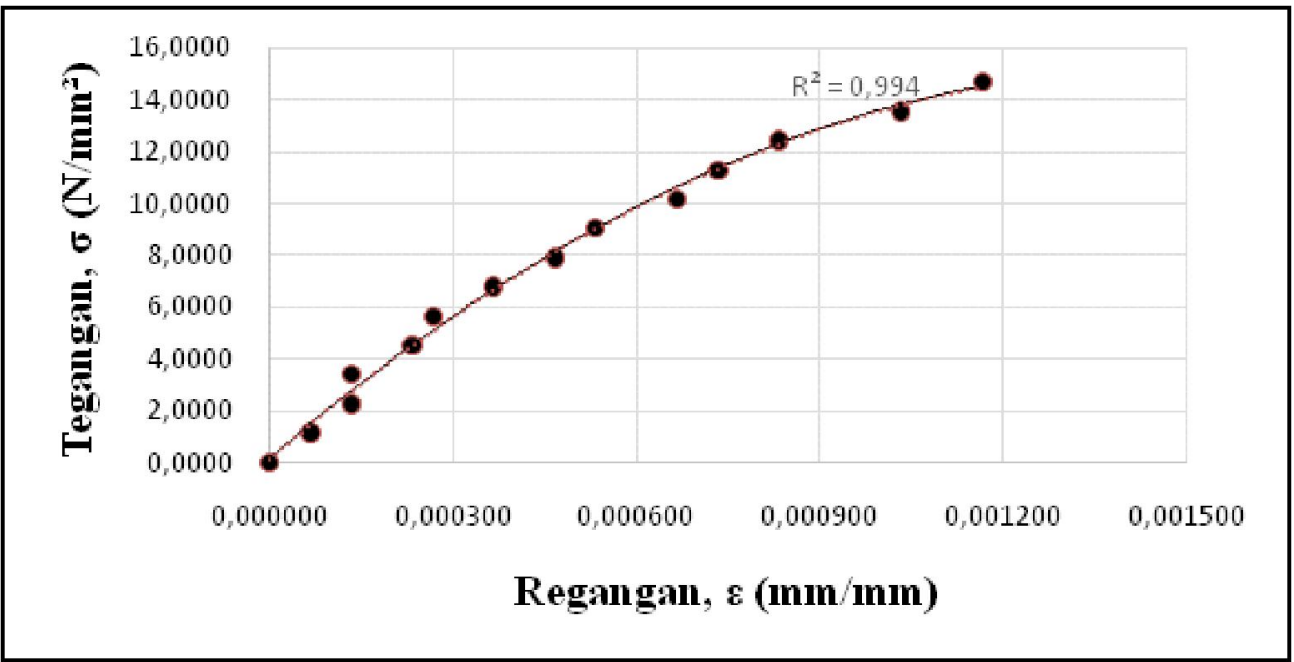

Gambar 8. Grafik Hubungan Antara Tegangan dengan Regangan Beton Non Pasir pada Suhu Bakar Agregat Lempung $1200^{\circ} \mathrm{C}$

Dari gambar $4.4 \mathrm{~s} / \mathrm{d} 4.8$ tersebut diatas, pasir secara keseluruhan dapat dilihat pada gambar maka hasil pengujian modulus elastisitas beton non berikut ini.

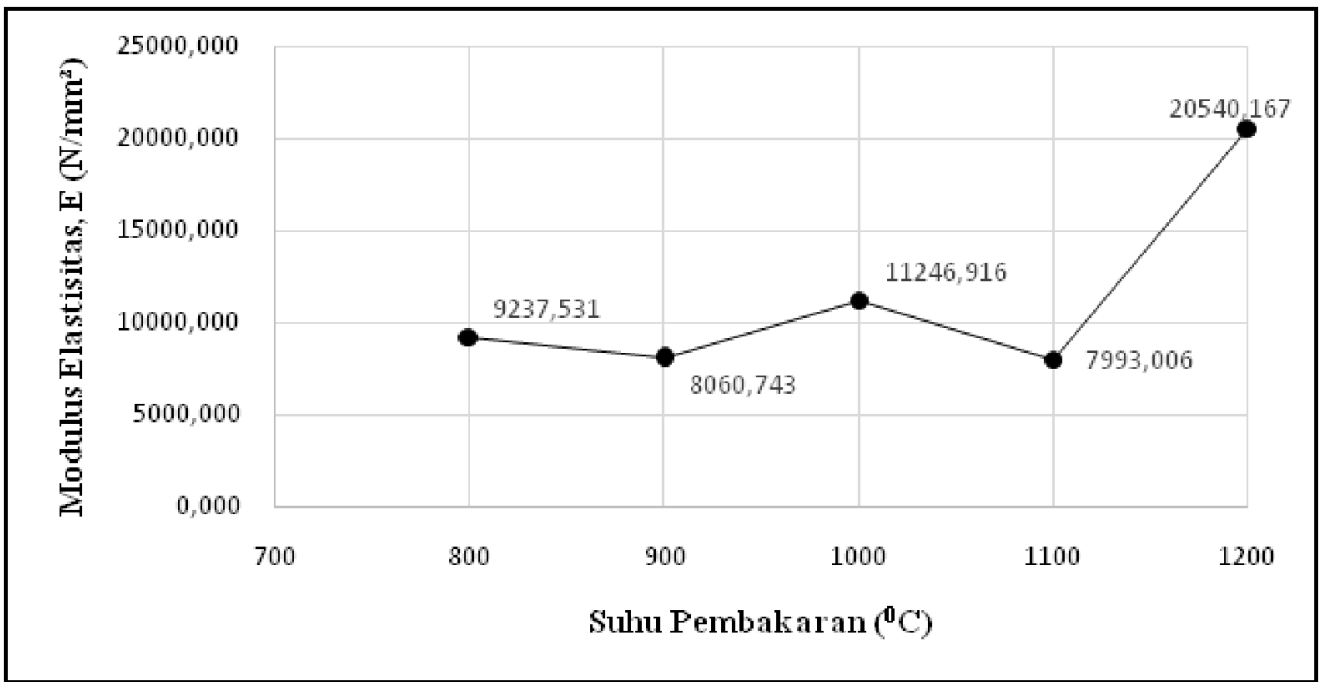

Gambar 9. Grafik Hubungan Antara Suhu Bakar Agregat Lempung dengan Modulus Elastisitas Beton Non Pasir 


\section{KESIMPULAN DAN SARAN}

\section{Kesimpulan}

- Semakin tinggi suhu bakar pada agregat lempung maka semakin baik pula karakteristik agregat yang dihasilkan dari pembakaran agregat lempung tersebut.

- Pengaruh kenaikan suhu pada pembakaran agregat lempung memberikan nilai kuat tekan beton non pasirnya semakin meningkat. Hal ini terlihat jelas pada hasil uji kuat tekan beton non pasir di masing-masing variasi suhunya, yakni pada suhu $800^{\circ} \mathrm{C}=7.93 \mathrm{MPa}$, suhu $900^{\circ} \mathrm{C}$ $=7.45 \mathrm{MPa}$, suhu $1000^{\circ} \mathrm{C}=11.83 \mathrm{MPa}$, suhu $1100^{\circ} \mathrm{C}=12.32 \mathrm{MPa}$, dan pada suhu $1200^{\circ} \mathrm{C}$ mencapai $14.10 \mathrm{MPa}$.

- Pengaruh kenaikan suhu pada agregat lempung terhadap kuat tarik belah beton non pasir dengan variasi suhu $800^{\circ} \mathrm{C}, 900^{\circ} \mathrm{C}, 1000^{\circ} \mathrm{C}$, $1100^{\circ} \mathrm{C}$, dan $1200^{\circ} \mathrm{C}$ memberikan kenaikan nilai kuat tarik belah betonnya sebesar $0.34 \mathrm{MPa}$, $0.22 \mathrm{MPa}, 0.52 \mathrm{MPa}, 0.58 \mathrm{MPa}$, dan 0.66 MPa, walaupun pada suhu $900^{\circ} \mathrm{C}$ terjadi sedikit penurunan kekuatan betonnya yang disebabkan pada kesalahan teknis dalam melakukan pencampuran beton tersebut.

- Untuk hasil pengujian porositas beton non pasir diperoleh nilai porositas beton yang sangat tinggi yakni mencapai $17.10 \%$ pada suhu $800^{\circ} \mathrm{C}$. Hal ini disebabkan karena didalam beton terdapat banyak ruang kosong yang berisikan udara sehingga berpotensi memberikan dampak buruk pada kekuatan betonnya. Nilai porositasnya pun sangat jauh berbeda ketika kita bandingkan dengan beton dengan agregat normal yang hanya mencapai $5.182 \%$.

- Hasil dari pengujian modulus elastisitas beton non pasir dapat diketahui bahwa ada pengaruh penggunaan suhu bakar agregat lempung terhadap nilai tegangan - regangan dan modulus elastisitas betonnya. Nilai modulus elastisitas optimum yaitu $20540.167 \mathrm{~N} / \mathrm{mm}^{2}$ pada suhu pembakaran $1200^{\circ} \mathrm{C}$, sementara minimumnya yaitu $7993.006 \mathrm{~N} / \mathrm{mm}^{2}$ pada suhu pembakaran $1100^{\circ} \mathrm{C}$. Hal ini tentu dipengaruhi juga oleh karakteristik kekuatan beton, sifat agregat, umur beton, jenis semen, kecepatan pembebanan, suhu, dan lain-lain.

\section{Saran}

- Dalam penelitian lebih lanjut disarankan sebelum melakukan penelitian, langsung ditetapkan perbandingan semen : agregat, misalnya $1: 2,1: 4,1: 6,1: 8$, dan seterusnya, karena sampai saat ini belum ada peraturan yang mengatur tentang beton non pasir.

- Pada peneliti selanjutnya disarankan untuk melakukan penelitian kembali dengan variasi suhu pembakaran agregat lempung diatas suhu $1200^{\circ} \mathrm{C}$ untuk mengetahui lebih dalam mengenai kekuatan beton non pasir yang dihasilkan.

- Dalam penelitian lebih lanjut sebaiknya menggunakan gradasi agregat kasar yang bervariasi untuk mengetahui jenis variasi agregat kasar yang ideal dalam peningkatan mutu dan kekuatan beton ringan non pasir.

- Pada peneliti selanjutnya, sebaiknya pada waktu pelaksanaan pengecoran, alat - alat maupun material yang digunakan diusahakan dalam kondisi SSD untuk mengatasi jumlah FAS yang benar-benar dibutuhkan oleh agregat.

\section{DAFTAR PUSTAKA}

Baasir, Hafni. 2005, Karakteristik pasca elastik dinding beton non-pasir dengan tulangan horisontal akibat beban statik, Tesis, Program Studi Teknik Sipil, Sekolah Pasca Sarjana, UGM, Yogyakarta

Buku Panduan Praktikum Teknologi Beton, UMM. Deddy dan Nunuy. 2007, Pemanfaatan Batu Berangkal Kapur Limbah Industri Sebagai Agregat Untuk Beton Non-Pasir. Murdock, L.J. and Brook, K.M., 1986, Bahan dan Praktek Beton, Jakarta.

Neville, A.M. and Brooks J.J., 1987, Concrete Technology, First Edition, Longman Scientific\& Technical, England.

Susilo, Indro. 2009, Pengaruh Penambahan Silika Fume Terhadap Kuat Tekan Dan Porositas Beton Non Pasir.

Tectona, Andrea. 2013, Pengaruh Limbah Keramik Sebagai Agregat Kasar Pada Beton Ringan (Non Pasir) Terhadap Berat Jenis, Porositas, Kuat Tekan, Dan Modulus Elastisitas. 
Tjokrodimuljo K. 2010, Serba-Serbi Beton-NonPasir Hasil Penelitian Di Laboratorium dan Uji Coba Di Lapangan, Universitas Gajah Mada, Yogyakarta.

Tjokrodimuljo K. 1992, Teknologi Beton, Nafiri, Yogyakarta. 